\title{
KOŁOWRÓT RELIGIJNYCH SYMBOLI: OD HRABALA DO CZESKIEJ PROZY LAT 90. XX WIEKU. PRZYPADEK „MEFITIS” MARTINA KOMÁRKA
}

\author{
Słowa kluczowe: czeska proza XX wieku, Martin Komárek, symbole religijne
}

Keywords: Czech prose of 1990s, Martin Komárek, religious symbols

1.

Zanim zajmiemy się czeską prozą lat 90. i symboliką religijną w powieści Martina Komárka, przywołajmy tekst wcześniejszy: Czułego Barbarzyńcę (1973) Bohumila Hrabala. Jest w nim scena, której symbolika zawsze mnie frapowała, a zarazem pokazuje ona złożoność semiotyki religijnej w czeskiej literaturze. Przyjaciele - narrator (Hrabal) i grafik (Vladimír Boudník), którego wspomnieniu opowieść poświęcono - trafiają w pobliże opuszczonego kościoła. W nadziei na nocleg niezbyt trzeźwi artyści podążają ku niemu, jak się okazuje, droga krzyżową. Na ołtarzu moszczą sobie legowisko z kościelnych sztandarów i gdy leżą w oślepiającym blasku księżyca... Boudník

[...] uniósł nogę, czubkiem buta trącił wieczną lampkę, która nie świeciła, i rozbujał to ozdobne naczynie, zawieszone na trzech cętkowanych łańcuchach, tak, że naczynie dosięgnęło tego chlorowego księżycowego światła i zapłonęło, oślepiło nas... wahadło wieczności za każdym razem znikało w ciemnościach jak nocny ptak, ale gdy pojawiało się w świetle księżyca, rozświetlało się to naczynie jak bażant nadzwyczajnej piękności, jak ptak Feniks, chwilę trwało w bezruchu, kiedy osiągnęło punkt szczytowy, po czym pod wpływem siły ciążenia i naturalnego ruchu buta Vladimira wracało w ciemność. [...] Vladimir przez całą noc miał otwarte oczy, patrzył na poruszającą się wieczną lampkę bez światła $[\ldots]^{1}$.

Jak rozumieć tę scenę? Wydarzenie zostało najprawdopodobniej zmodyfikowane, bo trudno przypuszczać, że w opuszczonej świątyni zachowała się cenna,

\footnotetext{
${ }^{1}$ Bohumil Hrabal, Czuły barbarzyńca. Teksty pedagogiczne, trans. Aleksander Kaczorowski (Izabelin: Świat Literacki, 1997), 39.
} 
wieczna lampka i kościelne feretrony. Jednak, niezależnie od stopnia mimetyzmu, zasadnicza pozostaje wymowa opisu. Widzę tu dwie alternatywne lektury. Pierwsza pokazywałaby Nieobecność Boga: wieczna lampka nie pali się. To człowiek na chwilę napełnia ją światłem, ale nie jest ono blaskiem Bożej obecności, lecz blaskiem sztuki, gestem performance przelotnie urzeczywistniającym idee fiat lux. Blasfemiczne działania bohaterów: rozwalonych na ołtarzu, potrącających nogą przedmiot kojarzony z Bożą osobą - są symbolicznym potwierdzeniem tego odczytania. Chrześcijański Bóg osobowy umarł; miejsca kultu popadły w ruinę, a ślady transcendencji wykorzystuje artysta - nowy bóg-stwórca.

Jest jednak możliwa inna interpretacja. Kluczem będzie ulubiony obraz Hrabala, który pisarz miał na biurku aż do śmierci - reprodukcja skrzydła poliptyku Hieronima Boscha Wizje zaświatów, a konkretnie część Przejście duszy ludzkiej do zaświatów. Centralnym elementem jest tunel, często opisywany przez ludzi, którzy doświadczyli śmierci klinicznej, zalewany na obrazie przez nieziemskie, „chlorowe” światło. Ku świetlistej cieśni dusze prowadzą anioły: patroni ostatecznej wędrówki ku wiecznemu życiu ${ }^{2}$. Hrabal nie był człowiekiem wiary w tradycyjnym znaczeniu, jego stosunek do religii pozostał pozainstytucjonalny, pozakonfesyjny, a przede wszystkim pełen paradoksów ${ }^{3}$. Mimo to, lub może właśnie dlatego, okazał się człowiekiem zdolnym do głębokiego doświadczania zdarzeń duchowych. Odrzucając wiarę w Boga osobowego, zarazem twierdził:

Ten Bóg jest we mnie, nie żeby to był Bohumil Hrabal, ale w środku duszy najdosłowniej czuję, że jestem spokrewniony z czymś, co jest wyższe niż ja sam, co ma wyższy ładunek, co jest transcendentne i zmierza zawsze ku metafizyce. Jego celem jest to prawdziwe dobro, które choć dokonuje niewielkiego postępu w świecie, to przecież człowiek w nie wierzy. Bóg jest dobrem. Oczywiście, problemem jest to, dlaczego używa również zła. W rzeczy samej to jest światło i cień ${ }^{4}$.

Idąc tropem tej deklaracji popatrzmy raz jeszcze na przytoczoną scenę z Czułego barbarzyńcy.

${ }^{2} \mathrm{O}$ znaczeniu obrazu dla Hrabala pisał Tomaš Mazal, Spisovatel Bohumil Hrabal (Praha: Torst, 2004), 46-47. Mazal łączył obraz ze stosunkiem Hrabala do Boga.

${ }^{3}$ Zwraca na to uwagę László Szigeti. Stwierdza: „Wydaje mi się, że jesteście ateistą, a przecież stale poszukujecie Boga. Co oznacza ten paradoks?”. Vide Bohumil Hrabal, Kličky na kapesníku. Román-interview, ptal se a odpovědi zaznamenal László Szigeti (Praha: Práce, 1990), 93. Brak tu miejsca na omówienie ciekawej odpowiedzi Hrabala. Tam, gdzie nie wskazano nazwiska thumacza, tekst podaję we własnym przekładzie.

${ }^{4}$ Ibidem, 40. Fakt, że pisarz kończy tę wypowiedź (mowa w niej dalej o Jezusie i Lao-c') deklaracją „Moim bogiem jest mój rodzinny język. Słowo...” (ibidem, 41) to przykład jego strategii paradoksów i zaprzeczeń. Te dwa fragmenty istnieją razem i wyrywanie jednego z nich z kontekstu drugiego byłoby interpretacyjną manipulacją. 
Obaj bohaterowie znaleźli się $\mathrm{w}$ przestrzeni, której symbolika sakralna (ołtarz, wieczna lampka, sztandary z wizerunkami pobożnych władców) odsłania „ontologiczne otwarcie”. Do tego punktu mężczyźni doszli drogą krzyżową i choć nie przemierzyli jej jak pobożni pielgrzymi, nie można zignorować faktu, że Hrabal postawił ich na takiej właśnie, symbolicznie nacechowanej ścieżce. "Chlorowe”, jak na obrazie Boscha, księżycowe światło, przyzywa ich ku transcendencji, podążania ku temu, z czym człowiek - jak mówił Hrabal - jest spokrewniony. Tak rozpoczyna się duchowa podróż bohaterów. A że zachowują się w niej niczym barbarzyńcy? Że ich gesty zdradzają świętokradczą dezynwolturę? Widzę w tym nie bezczelność, lecz animalną potrzebę ożywiania tego, co wydaje się martwe - czyż pies nie trąca zmarłego pana chcąc go ocucić? Czy koń poległego rycerza łbem lub kopytem nie stara się zmusić go do ruchu? Podobnie barbarzyńca wyrzucony z krainy ducha (rozprawa z Kościołem była w komunistycznej Czechosłowacji bezwzględna) - zamroczony alkoholem, a przecież uparty, niezmordowanie powtarza gest napełniający wieczną lampkę światłem. „Wahadło wieczności” pracuje całą noc i całą noc Vladimir wpatruje się w nie szeroko otwartymi oczami.

Co zatem wyraża symbolika przytoczonej sceny? Introdukcję ludzkiego panowania na gruzach zniszczonej religii? A może raczej pragnienie powrotu transcendencji? Religijnego kodu, konkretyzującego chrześcijańską metafizykę, bohaterowie nie respektują; gesty związane $\mathrm{z}$ religijnym rytem odrzucili, do tradycyjnej czci nie czują się zobowiązani, ale pozostaje w nich głód metafizyki, potrzeba czegoś „,co jest wyższe niż ja sam”. Hrabal na temat swoich lektur pisarzy metafizycznych i mistyków pisał:

Czytam tylko te fragmenty, które skierowane są ku metafizyce, bowiem tylko ona jedna jest zdolna wyjaśnić to wszystko, co się dzieje na ziemi, to, co historyczne, co czasem lub z zasady jest rzeczywistością szokującą i budzącą zgrozę 6 .

Zaś Leszek Kołakowski komentował dziwność naszych czasów:

Świat, w którym żyjemy, nie jest jednak światem ludzi przepełnionych pewnością, umocnionych w swej wierze lub niewierze. Żyjemy raczej w epoce wygnańców, uchodźców, banitów, istot błąkających się bez końca. „Żydów wiecznych tułaczy” poszukujących utraconej - duchowej lub fizycznej ojczyzny. W tym nomadycznym życiu nic już nie jest pewne, zagwarantowane, ostatecznie ustalone, nic poza samą wędrówką - nie jest dane w sposób wolny od pytań7.

${ }^{5}$ John A. McClure, Pótwiary. Literatura postsekularna w czasach Pynchona i Morrison, trans. et epil. Tomasz Umerle (Kraków: Wydawnictwo Uniwersytetu Jagiellońskiego, 2016), 15.

${ }^{6}$ Tomaš Mazal, op. cit., 378.

${ }^{7}$ Leszek Kołakowski, Czy Pan Bóg jest szczęśliwy i inne pytania, ed. Zbigniew Mentzel (Kraków: Wydawnictwo Znak, 2009), 58. 
2.

Ten obszerny fragment wstępny służył pokazaniu - na przykładzie jednego z najważniejszych czeskich pisarzy współczesnych - w jak niejednoznacznych ujęciach występuje tematyka religijna w literaturze naszych południowych sąsiadów. Zarazem pozostaje ona niedostatecznie opisana. W przypadku pisarzy, których konfesyjność jest wyrazista, krytycy i historycy literatury podejmują wyzwanie, ale w przypadku autorów pozostających poza obrębem instytucjonalizowanej wiary oraz tekstów będących zapisem nie ,[...] monolitycznej prawdy, ale wieloaspektowej przestrzeni enigmatycznych objawień", myśl krytyczna niechętnie się angażuje. Ideowo niesynchroniczne bogactwo tematyki duchowej w dziele Hrabala pozostawia, gdy idzie o jego opracowanie, poczucie niedosytu, mimo imponującej literatury przedmiotu dotyczącej interpretacji jego dorobku' Łatwiej też znaleźć prace poświęcone wpływowi wschodniej duchowości na jego pisarstwo (co niewątpliwie istotne, zwłaszcza gdy idzie o myśl Lao-c'), niż rozważania, w jaki sposób wprowadza on do tekstów przywołania, reinterpretacje i polemikę z chrześcijaństwem. A przecież materiał jest bogaty i nie ograniczony do „Kainowego znamienia”"10.

Odnoszę wrażenie, że czescy krytycy literaccy nie doceniają obecności i złożoności problematyki metafizycznej w ich literaturze, przede wszystkim w prozie; spirytualny wymiar poezji jest wnikliwie opisywany. Potwierdziły to sposoby porządkowania obrazu literatury czeskiej lat 90 . Przykładowo Michal Schindler, opisując stan czeskiego rynku wydawniczego po roku 1989, podkreślał ówczesną nadprodukcję książek. Wynikła ona $\mathrm{z}$ równoczesnego wydawania tego, co dotąd zakazane (emigracja, samizdat), nowych debiutów, wyjścia z cienia pisarzy dojrzałych, a piszących dotąd „do szuflady”, kontynuacji wydań twórców wcześniej dozwolonych, wreszcie napływu „komercji z Zachodu”, masowo wtedy tłumaczonej. Próbując opanować wylew literackiej magmy Schindler wprowadził porządkujące kategorie tematyczne, pominął jednak wyrazisty nurt problemowy, jakim w ówczesnym piśmiennictwie stała się tematyka duchowo-religijno-metafizyczna ${ }^{11}$.

${ }^{8}$ John A. McClure, op. cit., 14.

${ }^{9}$ Przykładowo Josef Zumr w artykule przedstawiającym biografię intelektualną pisarza i wpływ lektur na jego światopogląd ignoruje rolę myśli chrześcijańskiej. A przecież poza licznymi źródłami inspiracji, które wylicza, Hrabal czytał także Mistrza Eckharta, Jakuba Böhme’a, Novalisa, nie mówiąc już o licznych nawiązaniach do Pisma Św. Nieortodoksyjność, a często opozycyjność wobec chrześcijańskiej dogmatyki, nie umniejszają jej znaczenia w dziele pisarza. Vide Josef Zumr, „Ideová inspirace Bohumila Hrabal", in Hrabaliana. Sborník prací $k 75$ narozeninám Bohumila Hrabala (Praha: Prostor, 1990).

${ }^{10}$ Jacek Baluch, Kain wedtug Hrabala (Kraków: Wydawnictwo „scriptum”, 2007).

${ }^{11}$ Cf. Michal Schindler, „Na okraji české prózy let devadesátých”, Tvar, no. 3 (2000): 12-13. W wydanej w tymże roku 2000 rozprawie o charakterze socjologicznym, mającej prezentować stan czeskiego społeczeństwa, problematyka postaw religijnych w ogóle nie została uwzględniona. Vide Milan Tuček, Hana Friedlanderová, Češi na prahu nového tisíciletí, Praha 2000. 
Wśród osób, które problem dostrzegły, był m.in. Lubomír Machala ${ }^{12}$, jednakże wydane później, obszerne publikacje o charakterze historyczno-interpretacyjnym na temat literatury czeskiej lat 90 . XX wieku na powrót zagadnienie zmarginalizowały ${ }^{13}$. Temat Drugiego Przyjścia potraktowano jako modę wynikłą z millenarystycznych nastrojów Europy nasilających się w końcu drugiego tysiąclecia; modę równie przejściową, co religijne ożywienie w Czechosłowacji w połowie lat 80 . zeszłego stulecia ${ }^{14}$. Choć zainteresowanie tradycyjnym Kościołem w Czechach faktycznie nie wytrzymało próby czasu, nie oznacza to, iż literackie podjęcie tematu religijnego to także chwilowy kaprys. Uznanie zjawiska za kulturowo-literacką efemerydę zastanawia, gdy weźmiemy pod uwagę konsekwentny rozkwit badań nad problematyką współczesnej czeskiej religijności w bohemistycznych pracach z zakresu socjologii, socjologii religii, teologii, historii Kościoła. Ich autorzy często polemizują z opinią ukazującą Czechów jako naród głęboko zeświecczony ${ }^{15}$. W wypowiedziach, weryfikujących utrwalony stereotyp „społeczeństwa ateistów”, dostrzegamy nie tylko niuansowanie powszechnie znanych faktów, ale też próbę uchwycenia nowego (?), a może po prostu odmiennego przeżywania wiary, do czego Czesi, z racji ich historii, są szczególnie predestynowani.

Nowe trendy w myśleniu o współczesnym stosunku do wiary pozwalają dziś inaczej oceniać zjawisko także jako temat literacki. W optyce postmodernistycznej, która wcześniej narzucała interpretowanie motywów religijnych w czeskiej literaturze lat 90., dominowała koncepcja zabawy i gry. Zresztą w tamtym okresie, tj. na początku nowego millenium, powszechnie diagnozowano, że nadeszły

${ }^{12}$ Lubomír Machala, Literární bludiště. Bilance polistopadové prózy (Praha: Brána. Knížní klub, 2001). Krytyk zwraca uwagę na „polistopadową” (po aksamitnej rewolucji) popularność tematu Drugiego Przyjścia. Vide ibidem, 26. Pisał o tym także Holt Meyer, „Apokalyptická konfesionálnost a tradiční zlomy v tradici. Česká literárně-náboženská kultura roku 1632 a roku 1994”, in Česká literatura na konci tisíciletí, vol. 1 (Praha: Ústav pro českou literaturu AV ČR, 2001), 77-88.

${ }^{13} \mathrm{~W}$ pracy $V$ souřadnicích volnosti. Česká literatura devadesátých let dvacátého století $v$ interpretacích, ed. Petr Hruška, Lubomír Machala, Libor Vodička, Jiří Zizler (Praha: Academia, 2008) temat nie został potraktowany jako istotne zjawisko i sprowadzono go do zagadnienia nieśmiertelności. Vide ibidem, 293.

${ }^{14}$ Ideologiczny krach systemu komunistycznego spowodował w połowie lat 80 . w Czechosłowacji religijne ożywienie. Przejawiło się to m.in. ogromnym zainteresowaniem cyrylometodejskim jubileuszem - pielgrzymka na Velehrad stała się w roku 1985 największą demonstracją przeciwko władzy. Także późniejsza kanonizacja św. Agnieszki czeskiej (listopad 1989) oraz pielgrzymka Jana Pawła II do Czechosłowacji w kwietniu 1990 miały duży odzew społeczny.

${ }^{15}$ Vide David Václavík, Náboženství a moderní česká společnost (Praha: GradaPublishing. a.s., 2010). Autor powołuje się na tezę znanego socjologa P.L. Bergera, który pisał: „założenie, że żyjemy w zsekularyzowanym świecie, jest fałszywe. Dzisiejszy świat jest, z małymi wyjątkami, tak samo religijny, a w niektórych przypadkach nawet bardziej, niż był w przeszłości. To oznacza, że cały zbiór literatury stworzony przez historyków i socjologów i oznaczony tytułem „teoria sekularyzacji” jest w swej podstawie błędny”. Ibidem, 40. Tym tropem pójdzie wielu czeskich badaczy - zamiast poruszania się w polu alternatywy sekularyzacja-religijność trzeba poszukiwać specyfiki religijności naszych czasów. 
czasy, kiedy metafizyka nie może się odrodzić ani umrzećc ${ }^{16}$. W związku z tym Zygmunt Bauman pisał o zmierzchu etyki wynikającym z ostatecznego wyzwolenia podmiotu. Twierdził, że

etyka została potępiona jako któreś tam z rzędu nowoczesne kajdany (niegdyś może i użyteczne, dziś zbędne), etyka okazywała się jeszcze jednym złudzeniem, bez którego człowiek ponowoczesny może się obyć ${ }^{17}$.

„Druga strona”, w osobie biskupa Życińskiego, pisała o „bogu postmodernistów" ", o współczesnym odrodzeniu politeizmu wynikającym stąd, że wielkie idee religijne okazały się zbyt złożone dla współczesnego człowieka. Z tego powodu miał on kontaminować rozmaite elementy religijności, rozbijać i dowolnie zestawiać mity wcześniej porządkujące rzeczywistość, a obecnie zakwestionowane w ich całościowej funkcji jako odprysk upadku autorytetów ${ }^{19}$. Przywołane sygnalnie punkty widzenia wyznaczają pole obrazu postmodernistycznej religijności - jeszcze jednego elementu idei „wszystko uchodzi”. Idąc tym tropem czeski krytyk - całkowicie wbrew temu, co mówią dzieje kultury na temat czeskich fascynacji filozofią i religiami Wschodu - traktował ich współczesne przejawy jako skutek modnych trendów i powszechnej ucieczki od rzeczywistości: w mistycyzm, okultyzm, magię, bo to nie tylko formy samorealizacji, ale też dystansowania się od rzeczywistości pełnej przemocy i chaosu ${ }^{20}$.

Postsekularyzm ${ }^{21}$ zweryfikował autorytarne definiowanie „rzeczywistej” i ,zabawowej" religijności. Jeden ze współczesnych czeskich badaczy pyta, kto ma oceniać, co jest religijnością „naprawdę”, a co „na niby”, co lepszą, a co gorszą, prawdziwą i nieprawdziwą? ${ }^{22}$. Z perspektywy postsekularnej rozmaite przejawy

${ }^{16}$ Bogdan Baran, Postmodernizm i końce wieku (Kraków: Inter Esse, 2003), 238-242.

${ }^{17}$ Zygmunt Bauman, Etyka ponowoczesna, trans. Janina Bauman et JoannaTokarska-Bakir (Warszawa: PWN, 1996), 6.

${ }^{18}$ Józef Życiński, Bóg postmodernistów. Wielkie pytania filozofii we wspótczesnej krytyce moderny (Lublin: Wydawnictwo KUL, 2001), 36.

${ }^{19}$ Ibidem, s. 36.

${ }^{20}$ Tibor Žilka, „Modernismus a postmodernismus”, Tvar, no. 1 (1995): 5.

${ }^{21}$ Trudno ująć zjawisko postsekularyzmu w jednorodną definicję z uwagi na wielopostaciowość i aporyczność jego opisów. W artykule odwołuję się do tego, co stanowi podstawę wszelkich teorii postsekularnych: negowanie sposobu rozumienia zeświecczenia współczesnego świata i poszukiwanie nowych formuł opisu jego religijności.

${ }^{22}$ Na podstawie badania ISSP z roku 1998 poświęconego współczesnej religijności Dana Hamplova konstatowała że „osłabienie wpływu tradycyjnej religijności nie oznacza większego „trzeźwienia” świata, ale tworzy inny typ religijności. Czesi nie odrzucają z zasady wszystkiego, co nadprzyrodzone, ale raczej tradycyjne systemy religijne i zorganizowaną religijność". Prowadzi to do wiary koncentrowanej na człowieku, często polegającej na „fatalizmie” lub okultyzmie. Wielka część czeskiego społeczeństwa wierzy w jakiś typ „mistycznych” czy „okultystycznych” sił lub obiektów - np. 50\% ufa skuteczności amuletów. Vide Dana Hamplová, Náboženství a nadpřirozeno ve společností. Mezinárodní srovnáni na základě empiríckého výzkumu ISSP (Praha: Sociologický ústav AV ČR, 2000), 43-48; eadem, Náboženství v české společnosti na prahu 3. tisíciletí (Praha: Nakladatelství Karolinum, 2013), 30. 
religijności/duchowości traktuje się serio: bo jeśli nawet przybierają śmieszne formy, wynikają z nieusatysfakcjonowania „odczarowanym światem”, są przejawem tego, że racjonalistyczna, kojarzona $\mathrm{z}$ oświeceniem wizja rzeczywistości nie wystarczy, by rzeczywistość tę poznać; tym bardziej dobrze się w niej czuć. Cytowany już Leszek Kołakowski pisał:

Odkąd sto lat temu Nietzsche ogłosił śmierć Boga, nie widuje się już radosnych ateistów. Świat, gdzie człowiek zdał się na własne siły, uznał się za wolnego prawodawcę w kwestiach dobra i zła, gdzie - oswobodziwszy się wreszcie z łańcuchów Bożej niewoli - miał nadzieję odzyskać utraconą godność, ten właśnie świat przerodził się w miejsce niekończącej się troski i udręki. Nieobecność Boga stała się stale otwartą raną europejskiego ducha, choćby za sprawą sztucznych środków uśmierzających popadała w zapomnienie. Porównajmy bezbożny świat Diderota, Helvetiusa i Feuerbacha z bezbożnym światem Kafki, Camusa i Sartre'a ${ }^{23}$.

Można wyprowadzić stąd wniosek, że człowiek współczesny potrzebuje „ontologicznego otwarcia”, potrzebuje metafizyki, choć egzemplifikacje jego metafizycznego głodu wydają się śmieszne lub bluźniercze, gdy zwycięża rozpacz, że głodu nie zaspokoi. W tym aspekcie czeska literatura od XIX wieku, od Máchy, ma wiele do powiedzenia na temat „rany europejskiego ducha” i mówi to zaskakująco bogatym wielogłosem.

3.

W zmienionej perspektywie oglądu nieformalnych religijności to, co wcześniej wydawało się zabawą religią i zabawą z religii, jest odczytywane jako przejawy „nowych, osłabionych, hybrydycznych idiomów wiary” ${ }^{24}$. Przy czym słowo „osłabienie” należy rozumieć nie jako słabość, „letniość” doświadczenia religijnego, ale jako osłabienie ortodoksji, kościelnej formuły, w którą należy się wpisać, by zostać uznanym za wierzącego. Jeśli z tej perspektywy popatrzymy na czeską prozę lat 90 . XX wieku, to okaże się, że jej wyrazistym elementem jest twórczość autorów jednoczonych pokoleniowo, którzy na rozmaite sposoby podchodzą do tematyki wiary i zawierają to doświadczenie w bogatym, symbolicznym zapisie. Jáchym Topol (ur. 1962), Miloš Urban (ur. 1965), Martin C. Putna (ur. 1968), Martin Komárek (ur. 1961), nie tylko przynależą do jednej generacji, ale przede wszystkim w taki sposób rozprawiają się z materią duchową, że można na przykładzie ich utworów rozważać zjawisko postsekularnej religijności ${ }^{25}$. Powstaje pytanie, jak w ich dziełach religia, która w naturalny sposób posługuje się językiem symbolu, przedstawia sfery przeżyć szczególnie żywotnych dla współczesnego człowieka.

${ }^{23}$ Leszek Kołakowski, Czy Pan Bóg jest szczęśliwy i inne pytania, 59.

${ }^{24}$ John A. McClure, op. cit., 16.

${ }^{25}$ Wśród wymienionych pisarzy osobna jest osobowość M.C. Putny. Twórczość w/w artystów skłania do rozważenia istnienia (lub nie) zjawiska postsekularnej literatury, nie można jednak tego problemu podjąć w krótkim artykule. 
Utwór, którym się zajmę, to powieść Martina Komárka, czeskiego dziennikarza, pisarza, w swoim czasie głównego komentatora popularnego dziennika „Mladá fronta DNES”, felietonisty, satyryka. Syn byłego polityka sam intensywnie, z porażkami, ale też znaczącymi sukcesami, zajmował się polityką, obecnie jest posłem. Komárek uważa się i jest uważany za chrześcijanina, katolika, aczkolwiek jego stosunek do katolickiej dogmatyki pozostaje więcej niż swobodny. Esej pisarza, wydany w 2008 roku Bůh nezná budoucnost - Esej o víre, wzbudził uzasadnioną krytykę. Komárek jest autorem kilku utworów literackich, m.in. Dřevěná panenka (1990), Mefitis (1996), Králıček vám dodá Lesku (1998) (stanowią one luźno związaną trylogię), Smrt'áci, dwu tomów powieści Rytíri noci (2002/2003) i innych. Krytycy odnotowują pojawianie się kolejnych publikacji pisarza, ale w ich uwagach trudno dostrzec entuzjazm dla tej twórczości. Nie jest moim zamiarem kruszenie kopii o wybitność tego dzieła, ale świadomie wybieram teksty o średniej jakości literackiej uważając, że w nich - jak to niegdyś sformułował Michael Foucault - wyraźniej niż w dziełach wybitnych - ujawnia się episteme epoki. Traktuję więc tekst Komárka jako zapis współczesnego doświadczania religijności, a także impuls dla arcyważnego pytania: jak zakonserwowaną symbolikę religijną wpisać w język współczesności.

Komárek w powieści Mefitis nie oszczędza uczuć wierzącego tradycjonalisty. Jego narracja o Drugim Przyjściu została wmontowana w poetykę SF, miejscami fantasy, a nawet komiksu; co jednak istotniejsze - towarzyszy temu radykalna ingerencja $\mathrm{w}$ chrześcijańską dogmatykę. Jedna $\mathrm{z}$ linii fabularnych powieści (będąca wizją umierającego bohatera) rozgrywa się w przestrzeni kosmicznej, którą przemierza statek Emanuela - drugiego syna Bożego. Jego misja polega na dotarciu do Ziemi, zespoleniu się z głównym protagonistą, czyli dogorywającym Ludwikiem Rothem, i w ten sposób obdarzeniu ludzkości cząstką nieśmiertelności. Do tego bowiem momentu śmierć jest dla człowieka nieuchronnym końcem wszystkiego, w chwili zgonu pochłania go Nicość, jako że misja pierwszego syna Boga, Jezusa, nie powiodła się. Słynne słowa Ewangelii „Boże, mój Boże, czemuś mnie opuścił!” odczytywane są jako sygnał przerwania duchowego kontaktu dwu boskich bytów i klęski posłania Chrystusa. Ponowienie dzieła zbawienia ma miejsce u progu nowego millenium, w roku 1990. Emanuela wspomagają archaniołowie Michał i Gabriel obciążeni całym spectrum ludzkich, przyziemnych cech, wizualizowani w sposób, który nadaje im cechy mafijnych ochroniarzy.

W ogóle pozaziemski świat, zarówno w anheliczno-boskim, jak i demoniczno-lucyferycznym wymiarze posiada cechy i przywary zadziwiająco ludzkie: chla (czes. chlastá: autor używa języka pełnego wulgaryzmów i slangu), pali, łajdaczy się, żyje pragnieniem zysku, komfortu, kariery, intrygą i zawiścią. Kosmiczne pojedynki boskich i diabelskich sił wyglądają niczym skarykaturyzowane sceny z Gwiezdnych wojen lub gier komputerowych. 
W tym też kierunku poszły interpretacje krytyków. Petr Hrtánek jednoznacznie uznaje ten utwór za parodię i groteskę tematu paruzji ${ }^{26}$. Jest to odczytanie zgodne z modelem postmodernistycznym, pozostaje jednak pytanie, czy możemy uznać je za wystarczające? Jakie ważne treści zostały w ten sposób przeoczone? Hrtánek przywołuje wprawdzie deklarację książkowego bohatera, dystansującego się od własnej wizji nowego zbawienia:

Z drugiej strony ciężko jest uwierzyć, że Syn Boży przeprawia się w statku kosmicznym i prowadzi regularne gwiezdne bitwy z szatańskimi pułkami. W to nikt by nie uwierzył, ja również zbytnio w to nie wierzę. Jest to najprawdopodobniej metafora, która ma opisać przeprawę [Boga ku Ziemi - D.S.], bo dla ludzi misja jest obca i niezrozumiała. Taką samą metaforą było przed dwoma tysiącami lat poczęcie Jezusa Chrystusa. Dla zrozumienia naszych rodaków karmionych rozmaitymi poczwarami i pozaziemskimi potworami jest kosmiczna odyseja Emanuela znośniejsza, możliwa do przyjęcia ${ }^{27}$.

Z tej wypowiedzi czeski krytyk wyprowadza wniosek, że wpływ kultury masowej na społeczną wyobraźnię sprawia, iż najpoważniejszą tematykę religijną trzeba animować za pomocą symboli wywiedzionych z rozrywkowego kina. W ten sposób paruzja staje się obiektem parodii i zabawy groteską ${ }^{28}$.

Hrtánek dotyka problemu poważnego, ale w jego interpretacji zatrzymuje się w pół drogi. O tym, że chrześcijaństwo, by mogło przemawiać dziś, musi zmienić język, pisało wielu badaczy, m.in. Leszek Kołakowski. Akcentował on dystans „[...] dzielący nasze codzienne doświadczenie i tradycyjny język teologiczny”"29, co sprawia, że język ten stał się niezrozumiały dla ludzi współczesnych:

Można zasadnie powiedzieć, że chrześcijaństwo musi zmienić język swojej doktryny i dopasować się do cywilizacyjnych przeobrażeń. Czyniło to już nieraz - choć nie bez gigantycznych trudności - a podczas takiego procesu akomodacji zawsze rodzi się niebezpieczeństwo, że w trakcie poszukiwań nowej formy zapomni się o treści ${ }^{30}$.

Zapytajmy, jaka treść powieści Komárka została zapomniana w wyniku koncentracji na formie, czyli nowej (parodystycznej) symbolice przedstawienia paruzji? Otóż na drugi plan odsunięto zasadniczy przekaz utworu, tytułowy mefitis, będący metaforą nie tylko choroby, ale cierpienia w ogóle. O tym problemie za chwilę.

Zatrzymajmy się chwilowo na kwestii nowej symboliki mogącej odrodzić język religii. Taka możliwość bywa opatrywana znakiem zapytania, a nawet konkluzją, że dzisiejszy człowiek nie jest w stanie wyobrazić sobie Boga. W tym kontekście

\footnotetext{
${ }^{26}$ Petr Hrtánek, Kacíri, rouhači, ironikové (v současné české próze) (Brno: Host, 2007).

${ }^{27}$ Martin Komárek, Mefitis (Praha: Triáda, 1996), 111.

${ }^{28}$ Petr Hrtánek, op. cit., 106-107.

${ }^{29}$ Leszek Kołakowski, Czy Pan Bóg jest szczęśliwy $i$ inne pytania, 66.

${ }^{30}$ Ibidem.
} 
rozpatrywana powieść Komárka pokazywałaby nieudolność współczesnej wyobraźni i jej infantylizację, widoczną zwłaszcza wtedy, gdy zadawane jest najtrudniejsze z pytań: o relację Boga i zła. Autor Mefitis konwencjonalnie odświeża problem możliwości myślenia o Bogu po holokauście, a jego bohaterowie rozwiązują dylemat naruszając dwie kanoniczne zasady chrześcijańskiej dogmatyki: kwestionują wszechmoc Boga oraz nieśmiertelność duszy ludzkiej. Efektem tego jest symbolizacja Boga jako zdziecinniałego staruszka, który bawi się w elizjum stylizowanym na kształt Disneylandu: ma tam cienie pomordowanych Żydów i okazuje im rozmaite fawory. Odjęto im „miłosiernie” pamięć okrutnej śmierci, nie są oni też świadomi nicości, która ogarnęła ich w chwili zgonu. Bóg może uspokajać wyrzuty sumienia dopieszczając swoje marionetki. Ponowienie misji zbawienia jest więc niezbędne, bo cokolwiek przydarzy się człowiekowi w życiu doczesnym, okaże się niczym w perspektywie wieczności; podobnie jak okrutne tortury, które zadają sobie diabły i aniołowie: pogruchotane kości, wybite zęby to tylko ,jedna chwilka”. W ten sposób Drugie Przyjście miałoby odkupić błąd Boga, który w przystępie pychy i rywalizacji z Szatanem (nawiązanie do Księgi Hioba) nakazał stworzenie bytu nieodwołalnie śmiertelnego.

Ta logika, która miałaby rozwikłać skandal zła, jest równie naiwna, jak wizje rosłych aniołów-bodyguarḍów, hologramowych masek, za którymi kryją swoje oblicza i bitew toczonych w kosmicznej przestrzeni. Trzeba jednak zapytać, czy naiwność, a także herezja przytoczonego rozumowania, stanowią „rozwiązanie autorskie", czy może są parodią współczesnego borykania się z problemem unde malum? Opowiadałabym się za drugą interpretacją, a argumentem są obecne w powieści przywołania intertekstualne. Brak tu miejsca, by je szerzej omówić, zwrócę więc uwagę tylko na dwa przykłady.

Czyż nie jest zastanawiające, że ulubioną książką Lucyfera jest Školak Kája Mař́k, powieść pisarki Marie Wagnerovej z roku 1926? Niezwykle popularna, zakazana przez komunistów, wznowiona na początku lat 90. i błyskawicznie wykupiona, ukazywała tradycyjny, czarno-biały świat regulowany katolickimi wartościami. Jej naiwność, idealizacja, konserwatyzm powinny, tak by się wydawało, być anachronizmem w czasach współczesnych. A przecież wznowienie rozebrano „na pniu” i - by zaspokoić potrzeby czytelników - pojawiły się fikcyjne kontynuacje powieści. Nic dziwnego, że książka cieszy Lucyfera: obraz świata, w którym zło jest karane, a dobro wynagradzane, może tylko napędzać mu wyznawców. Każde „potknięcie się” Opatrzności jest w tym kontekście skandalem, powodem złamania wiary i przejścia na stronę filozofii diabelskiej: tyle naszego, co użyjemy.

Z drugiej strony czy jest przypadkiem, że archanioł Gabriel czyta jansenistyczne kazania i ukrywa się z tym kacerstwem przed Emanuelem? ${ }^{31}$. Janseniści

\footnotetext{
${ }^{31}$ Martin Komárek, Mefitis, 73.
} 
podkreślali przekonanie, że „Bóg nam nic nie jest dłużny”32, a stwarzając naturę (a zatem także człowieka) odsłonił On szczególnie głęboką szczelinę między sobą jako Twórcą, a stworzeniem ${ }^{33}$. W powieści ten problem wciąż powraca, a wraz z nim ewokowana potrzeba zasypania przedziału. Powinniśmy traktować to jako postulat opatrzony odautorską aprobatą? Czy może kolejny, dany przez autora, przykład dzisiejszej ignorancji i arogancji w sprawach wiary, zawodnej chęci, by prawami logiki (i sprawiedliwości) oceniać Boga?

W twórczości jansenistów jest jeszcze jeden problem, szczególnie mocno wyakcentowany, który pojawi się także w powieści Martina Komárka. Otóż jest to przeświadczenie, że świat, w którym żyjemy, nie jest tym, do którego przynależymy ${ }^{34}$. Człowiek odkrywa tę prawdę w szczególnych momentach swojej egzystencji. Odsłoną jest przede wszystkim choroba i cierpienie. Nic dziwnego, że wyznawcą jansenizmu stał się Blaise Pascal, przedwcześnie zmarły i przez większość życia torturowany przez własne ciało. Ból, jak pisała Hannah Arendt, to „,...] prawdziwie graniczne doświadczenie pomiędzy życiem jako „byciem wśród ludzi" (inter homines esse) a śmiercią, jest tak subiektywny i oddalony od świata rzeczy i ludzi, że w ogóle nie może przybrać postaci zjawiska" "35. Ból w powieści Komárka, będący skutkiem choroby mefitis ${ }^{36}$ objawia się czytelnikowi na pierwszych kartach powieści w brutalnej, fizycznej, wręcz fizjologicznej odsłonie. Jest on także metaforyzowany wtedy, gdy zyskuje sens politycznej diagnozy na temat moralnego stanu czeskiego społeczeństwa. Na planie podstawowym jest to jednak ból w wymiarze antropologicznym. Ludwik, cierpiący na mefitis, jest przyrównywany do Chrystusa, ale wydaje się, że bliżej mu do Pascala (także Hioba). Z chorobą, na którą cierpi, nie da się żyć, ale nie można też umrzeć wystarczająco szybko. Ból i upokorzenie, jakie ciało zadaje inteligentnemu, wrażliwemu mężczyźnie - choćby scena szpitalnego obrządku mycia - nie są metaforą, ale materialną dosłownością. Metafora wkracza wtedy, gdy ma zostać nadany sens: wtedy przywołane jest Drugie Przyjście. Jednak, jak już pisałam,

\footnotetext{
${ }^{32}$ Leszek Kołakowski, Bóg nam nic nie jest dhużny. Krótka uwaga o religii Pascala i o duchu jansenizmu (Kraków: Wydawnictwo Znak, 1994).

${ }^{33}$ Ibidem, 88-89.

${ }^{34}$ Ibidem, 112-113.

${ }^{35}$ Hannah Arendt, Kondycja ludzka, trans. Anna Lagodzka (Warszawa: Fundacja Aletheia, 2000), 57.

${ }^{36}$ Pełne objaśnienie symboliki pojęcia mefitis wykracza poza objętościowe ramy tego tekstu. W kulturze rzymskiej Mefitis stanowiła (obok Febris i Cloaciny) jedną z personifikacji choroby prowokowanej przez szkodliwe opary i trujące gazy. Autor odwołuje się do objaśnienia zawartego w Słowniku Rigera (Rigrův slovník naučny), gdzie mefitis to duszące i niezdrowe opary zamkniętych pomieszczeń i przestrzeni, kloak, gdzie gniją ludzkie i zwierzęce resztki, cmentarzy. Pojęcie jest w powieści nośnikiem symboliki metafizycznej, ale też politycznej kojarzonej z konsekwencjami inwazji 1968 roku i złamania w jej wyniku czeskiego społeczeństwa. Wymiar polityczny symbolu nie jest tu (z braku miejsca) omawiany, aczkolwiek to dość sztuczne rozdzielenie znaczeń.
} 
metafora przesuwa nas w świat wyobrażeń tak naiwnych, że sam bohater waha się, czy uznać je za objawienie, czy malignę agonii wywołanej próbą samobójczą, a potem terminalną fazą choroby.

Uwzględniając te „widełki” realności cierpienia oraz konwencjonalności symbolicznego języka, który mówi o jego odkupieniu - czy możemy uznać, iż temat paruzji „oddano” parodii i grotesce? Niekoniecznie. Powtarza się interpretacyjna alternatywa, tak jak w przypadku przytoczonej na początku artykułu sceny z utworu Hrabala: możemy uznać, że „Bóg umarł” (w powieści Komárka drugi Zbawiciel także zawodzi) albo stwierdzić, że choć nasza wyobraźnia, nasza symbolika, pozostają w kwestii Boga nieprzekonujące i łatwe do ośmieszenia, to potrzeba ponownego „zaczarowania” świata wymyka się regułom postmodernistycznej gry. McClure pisze, że dzieła traktowane przez niego jako postsekularne nie wieszczą „triumfalnego odrodzenia religii” (w przeciwieństwie do New Age $)^{37}$, i choć na powrót „zaczarowują” świat, to „sam proces zaczarowania prezentowany jest jako ryzykowny, a jego efekty - niepewne"38. Podobne zjawisko zachodzi w powieści Komárka: stan śpiączki bohatera i uwięzionego w jego ciele Boga nie są śmiercią definitywną. W końcu „Pan Bóg przyjdzie, jeśli mu trochę pomożemy" 39 .

\section{TURNSTILE OF RELIGIOUS SYMBOLS: \\ FROM HRABAL TO CZECH PROSE OF THE 90S OF THE $20^{\mathrm{TH}}$ CENTURY. CASE OF MARTIN KOMÁREK'S “MEFITIS”}

\section{S u m m a ry}

The ambiguous presence of religious themes in Czech prose of the end of the twentieth century is not sufficiently described by literary scholars. Czech literary critics did not appreciate the importance of this phenomenon. From the post-secular perspective it is clear that religious themes in literature are a manifestation of the search for metaphysics, crossing the rationalist vision of the world. The author reconstructs the symbolic language used by Martin Komárek when raising the subject of religion. His novel Mefitis is a record of contemporary experience of religiousness.

\footnotetext{
${ }^{37}$ John A. McClure, op. cit., 19.

${ }^{38}$ Ibidem.

${ }^{39}$ Martin Komárek, Mefitis, 72.
} 